\title{
Kandungan Total Fenolat pada Ekstrak Rhizophora sp Dari Teluk Awur, Jepara
}

\author{
Ali Ridlo*, Endang Supriyantini dan Sri Sedjati \\ Departemen IImu Kelautan, Fakultas Perikanan dan IImu Kelautan, Universitas Diponegoro \\ Jl. Prof Sudharto, SH., Tembalang, Semarang, Indonesia 50275 \\ Email : aliridlo26@gmail.com
}

\begin{abstract}
Total Phenolic Contents of Extract Mangroves Rhizophora sp. from Teluk Awur, Jepara
\end{abstract}

The antioxidant activity and total phenolic content of 18 extracts from different plant parts (leaves and stem bark) of 3 mangroves R. mucronata, R. apiculata andR. stylosa from Teluk Awur, Jeparawere examined. The content of total phenolics in the extracts was calculated as gallic acid equivalent (GAE) and antioxidant activity was estimated as $I C_{50}$ values using 1,1-diphenyl-2picrylhydrazyl (DPPH). The samples were extracted with n-hexane, ethyl acetate, and methanol respectively. The result showed that ethyl acetate extract of stem bark of $R$. apiculata holded the highest antioxidant activity with IC $5047.52 \mathrm{ppm}$. Rates of total phenolic content ranged from $5.15 \pm$ 1.02 to $64.79 \pm 2.75 \mathrm{mg}$ GAE/g. There was a significant correlation between total phenolic content and antioxidant activity. The results indicated promising mangrove Rhizophora sp. for the utilization as significant source of natural antioxidant.

Keywords: antioxidant activity; DPPH; mangrove; Rhizophora sp.; total phenolics

\begin{abstract}
Abstrak
Telah dilakukan uji kandungan total fenolat dan aktivitas antioksidan 18 ekstrak dari bagian tanaman (daun dan kulit batang) 3 spesies mangrove asal Teluk Awur Jepara, yaitu mangroves $R$. mucronata, $R$. apiculatadan $R$. stylosa. Kandungan total fenolat ditentukan sebagai ekuivalen asam galat (GAE) dan aktivitas antioksidan ditentukan berdasarlnhibition Concentration 50 (IC $C_{50}$ ) dengan menggunakan radikal bebas DPPH (1,1-diphenyl-2-picrylhydrazyl). Sampel diekstraksi secara bertngkat menggunakan n-heksana, etil asetat dan metanol. Hasil penelitian menunjukkan ekstrak etil asetat kulit kayu mangrove $R$. apiculata memiliki aktivitas antioksidan terbaik dengan $I C_{50} 47.52 \mathrm{ppm}$. Nilai kandungan total fenolat ekstrak berkisar antara $5.15 \pm 1.02$ sampai $64.79 \pm 2.75$ $\mathrm{mg} \mathrm{GAE} / \mathrm{g}$. Terdapat korelasi kuat antara kandungan total fenolat dengan aktivitas antioksidan. Hasil ini menunjukkan bahwa mangrove Rhizophora sp. dapat dijadikan sebagai sumber senyawa antioksidan alami.
\end{abstract}

Kata kunci : aktivitas antioksidan; total fenolat; DPPH; mangrove; Rhizophora sp.

\section{PENDAHULUAN}

Rhizophora merupakan tumbuhan mangrove yang banyak terdapat di Indonesia,3 jenis diantaranya ditemukan di Teluk Awur Jepara yaitu R. mucronata, $R$. apiculata dan $R$. stylosa. Secara tradisional tanaman mangrove telah dimanfaatkan sebagai bahan makanan dan minuman, sayuran, bahan penyamak kulit (tanning), zat warna, pelangsing, antidiare dan antimuntah (Abidin et al., 2013). Ekstrak tanaman mangrove menunjukkan aktivitas biologis seperti antibakteri, antimalaria, antikarsinogen, dan antiviral (Mohsen \& Ammar, 2009; Abidin et al., 2013; Mouafi et al., 2014; Yogananth, et al., 2015; Cruz et al., 2015).Beberapa kajian menunjukkan bahwa tumbuhan mangrove juga berpotensi sebagai antioksidan (Banerjee et al., 2008; 
Mohsen and Ammar, 2009; Patra et al., 2011; de-Faria et al., 2012; Jacoeb et al., 2013;Purwaningsih et al., 2013; Suh et al., 2014; Cruz et al., 2015; dan Paputungan et al., 2017).

Senyawa fenolat merupakan metabolit skunder yang banyak terdapat dalam tumbuhan dan berperan dalam pertumbuhan, reproduksi dan pertahanan diri (Pawar and Dasgupta, 2016). Rhizophora sp. mengandung senyawa fenolat benzophenon, flavonoid, asam fenolat, tannin dihidroflavonol, asam kafeat, asam vanilat, asam p-hidroksi benzoate, asam lemak, alkaloid, kumarin, fenol dan polifenol, quinon, resin, saponin, fitosterol, xanthoprotin, pigmen dan gula (Abidin et al., 2013). Senyawa fenolat seperti asam fenolat, flavonoid, quinon, lignan, stilbena dan tanin dalam mangrove dapat berfungsi sebagai penangkap radikal bebas (Roby et al., 2013). Radikal bebas seperti Reactive Oxygen Species (ROS), Reactive Nitrogen Species (RNS)danReactive Sulfur Species (RSS) dihasilkan darireaksi oksidasi dalam sel dan dapat memicu terjadinya reaksi berantai (chain reaction) dalam sel.Radikal bebas menyerang semua biomolekul, terutama asam lemak tak jenuh ganda penyusun membran sel membentuk lipidperoksida yang bersifat sangat merusak. Radikal bebas merupakan salah satu penyebab timbulnya berbagai penyakit degeneratif seperti kanker, aterosklerosis, stroke, jantung, gagal ginjal, hipertensi, katarak, dan penuaan dini (Saha et al., 2008). Aktivitas radikal bebas dalam tubuh dapat diredam dengan pemberian antioksidan (Mohsen dan Ammar 2009). Antioksidan merupakan spesies kimia pemberi elektron (electron donor) atau reduktan yang dapat menghambat, mencegah atau memperlambat reaksi oksidasi. Antioksidan bekerja dengan cara mendonorkan elektron atau hidrogen kepada radikal bebas sehingga menjadi stabil(Nimse dan Pal, 2015).

Senyawa flavonoid (fenolat) dapat berfungsi sebagai antioksidan (Malik et al., 2017). Potensial reduksi radikal flavonoid lebih rendah daripada radikal alkil peroksil dan superoksida, sehingga flavonoid dapat mereduksi / menonaktifkan dan meredam radikal bebas. Polifenol bersifat multifungsi karena dapat berperan sebagai agen pereduksi, pendonor hidrogen, peredam terbentuknya oksigen singlet $\left({ }^{\prime} \mathrm{O}_{2}\right)$, radikal oksigen, dan pengkhelat logam (Hamlaovi, 2018). Senyawa fenolat/flavonoid memproteksi DNA dari radikal hidroksil ${ }^{*} \mathrm{OH}$. Kompleks flavonoid-Cu atau flavonoid-Fe mencegah terbentuknya ROS (Lü et al., 2010). Senyawa fenolat memutus reaksi berantai radikal bebas dan mendonorkan atom hidrogennya membentuk radikal bebas stabil. Struktur dan letak gugus hidroksil $(-\mathrm{OH})$ dalam senyawa fenolat berperan penting terhadap aktivitas antioksidan (Nimse dan Pal, 2015). Aktivitas antioksidan mengindikasikan adanya kemungkinan aktivitas biologis lainnya, karena antioksidan mampu menghilangkan gangguan metabolik dan keadaan patologik seperti kardiovaskular, respiratorik, infeksi, peradangan, karsinogenesis dan penuaan. Antioksidan membantu mengatasi kerusakan oksidatif akibat radikal bebas atau Spesies Oksigen Reaktif. Kerusakan oksidatif ini terlibat dalam patogenesis berbagai penyakit seperti alzheimer, parkinson, dan sklerosis lateral amiotopik, penyakit pada gigi dan gusi (periodontal) penyakit kardiovaskular, hipertensi, dan diabetes (Waddington et al., 2008).

Penelitian ini bertujuan menentukan aktivitas antioksidan ekstrak daun dan kulit batang mangrove $R$. mucronata, $R$. apiculata dan $R$. stylosa dari Teluk Awur Jepara dengan metode transfrer elektron / hidrogen menggunakan radikal bebas DPPH (1,1-difenil-2-pikrilhidrazil) secara in vitro.

\section{MATERI DAN METODE}

Dalam penelitian menggunakan daun dan kulit batang mangrove $R$. mucronata, $R$. apiculatadan $R$. stylosa yang diambil dari kawasan mangrove Teluk Awur Jepara. Sampel diambil dari 4 tegakan yang berbeda, dicampur, kemudian dibersihkan dan dicuci dengan air tawar, dicacah, dikeringkan, kemudian digiling sampai halus (Banerjee et al., 2008) 
Ekstraksi dilakukan dengan cara
maserasi bertingkat menggunakan pelarut $\mathrm{n}$-heksana, etil asetat, dan metanol (Suh et al., 2014). Sampel halus sebanyak $50 \mathrm{~g}$ dimaserasi dalam $400 \mathrm{~mL} \mathrm{n}$ heksana selama 24 jam pada suhu ruang \pm $27 \circ$ C, lalu disaring. Residu dimaserasi kembali selama 2 jam lalu disaring, filtratnyadiuapkan menggunakanrotary evaporator pada suhu $37{ }^{\circ} \mathrm{C}$. Residu dimaserasi kembali berturutturut dalam etil asetat dan metanol dengan cara yang sama seperti di atas, kemudian dievaporasi sampai diperoleh ekstrak.

\section{Uji Aktivitas Peredaman Radikal Bebas DPPH}

Tiga $\mathrm{mL}$ larutan ekstrak dengan konsentrasi 50, 100, 150, 200, 250, 300, 350, 400 ppm ditambah $1 \mathrm{~mL}$ DPPH 0,1 mM, kemudian diinkubasi selama 30 menit pada suhu ruang $\left(27^{\circ} \mathrm{C}\right)$ dan diukur absorbansinya pada panjang gelombang 516,5 nm. AktivitasPeredaman radikal DPPH dihitung menggunakan rumus (Suh et al., 2014). Aktivitas antioksidan dinyatakan dalam $I_{5}$ yang dihitung dengan regresi linier antara konsentrasi ekstrak versus aktivitas peredaman (\%).

\section{Pengukuran Kandungan Total Fenolat}

Uji kandungan total fenolat dilakukan menggunakan reagen Folin-Ciocalteu dengan asam galat sebagai standar (Mohsen dan Ammar, 2009). Disiapkan sebanyak $2 \mathrm{~mL}$ Asam galat dengan konsentrasi 5, 10,15, 20 dan 25 ppm, kemudian ditambahkan $5 \mathrm{~mL}$ akuades dan $0,5 \mathrm{~mL}$ reagen Folin-Ciocalteu, Ialu didiamkan selama 3 menit. Setelah itu ditambahkan 1 $\mathrm{mL}$ larutan $\mathrm{Na}_{2} \mathrm{CO}_{3} 5 \%$ dan diinkubasi pada suhu ruang $\left(28^{\circ} \mathrm{C}\right)$ selama 1 jam dalam kondisi gelap. Larutan tersebut diukur absorbansinya pada panjang gelombang $725 \mathrm{~nm}$. Cara yang sama dilakukan pada masing-masing ekstrak. Kandungan total fenolat dihitung menggunakan rumus (Ghafar, 2010).

\section{Analisis Data}

Data dianalisis dengan uji regresi dan korelasi untuk menduga korelasi antara kadar total senyawa fenolat terhadap aktivitas peredaman radikal bebas DPPH. Normalitas dan homogenitas data diuji dengan ANOVA.

\section{HASIL DAN PEMBAHASAN}

Pada ketiga jenis mangrove, rendemen ekstrak metanol selalu lebih tinggi dibandingkan dengan ekstrak etil asetat dan n-heksana, sedangkan ekstrak n-heksana hampir selalu paling rendah(Tabel 1). Rendemen tertinggi dicapai pada ekstrak metanol kulit batang R. mucronata, yaitu $25,38 \%$, diikuti ekstrak metanolkulit batangR. apiculata dan ekstrak metanol daunR. mucronata. Hal ini menunjukkan bahwa kulit batang dan daun mangrove lebih banyak mengandung senyawa polar seperti alkohol, aldehid dan fenol daripada senyawa semi polar dan non polar seperti hidrokarbon dan asam lemak (Abdurahman et al., 2016).

Dalam satu spesies mangrove, rendemen ekstrak kulit batang selalu lebih besar daripada daun, yang berarti kulit batang lebih banyak mengandung zat ekstraktif daripada daun (Banerjee et al., 2008; Malik et al., 2017). Kandungan total fenolat bervariasi diantara ketiga spesies Rhizophora sp. Secara umum ekstrak kulit batang mengandung lebih banyak senyawa fenolat daripada daun. Kulit batang mangrove Rhizophora sp. Banyak mengandung senyawa golongan fenolat seperti polifenol, flavonoid, katekin dan tannin yang berfungsi struktural dan pertahanan diri (Abdurahman et al., 2016). Kandungan total fenolat kulit batang berkisar antara 5,39mg GAE/g (ekstrak metanol kulit batang $R$. apiculata) sampai $64,79 \mathrm{mg} \mathrm{GAE} / \mathrm{g}$ (ekstrak etil asetat kulit batang $R$. apiculata), sedangkan pada daun antara 5,13 $\mathrm{mg}$ GAE/g(ekstrak n-heksana daun R. stylosa) sampai $54,48 \mathrm{mg}$ GAE/g(ekstrak etil asetat daun R. apiculata) (Gambar 1). Hasil ini sesuai dengan mangrove dari Setiu Wetland Malaysia (Malik et al., 2017)

Hasil penelitian juga menunjukkan senyawa fenolat dapat terekstraksi dengan ketiga pelarut yang digunakan, sehingga diduga ketiga jenis mangrove tersebut mengandung senyawa fenolat yang bersifat non polar, semi polar dan polar dengan 
komposisi yang berbeda. Menurut Close dan McArthur (2002), kadar total fenolat tumbuhan mangrove bervariasi tergantung pada spesies, bagian tanaman (kulit batang, daun dan akar) dan kondisi lingkungannya, serta kadarnya meningkat pada lingkungan yang tertekan (Banerjee et al., 2008; Rahim et a.l, 2008; Suh et al., 2014).

Uji aktivitas antioksidan terhadap 18 ekstrak menunjukkanl $C_{50}$ ekstrak kulit batang berkisar antara 47,52 ppm sampai 289,52 ppm, sedangkan untuk ekstrak daun antara 72,15 ppm sampai 342,94 ppm (Gambar 2).

Terdapat 1 ekstrak memiliki aktivitas sangat kuat $\left(\mathrm{I} \mathrm{C}_{50}<50 \mathrm{ppm}\right)$ yaitu ekstrak etil asetat kulit batang $R$. apiculata, 3 ekstrak memiliki aktivitas kuat (IC 5050 - 100 ppm) yaitu ekstrak n-heksana kulit batang $R$. mucronata, ekstrak etil asetat daun $R$. apiculata dan ekstrak metanol daun $R$. stylosa. Lima ekstrak memiliki aktivitas sedang (IC50 100 - 150 ppm), 3 ekstrak memiliki aktivitas lemah (IC $50150-200$ ppm) dan 6 ekstrak bersifat sangat lemah (IC $50>200$ ppm).
Ada korelasi kuat $(0,693)$ antara total fenolat dengan aktivitas antioksidan $\left(\mathrm{IC}_{50}\right)$ dengan $R^{2}=0,481$. Uji ANOVA menunjukkan bahwa kandungan total fenolat berpengaruh terhadap $I_{50}$. Semakin kuat aktivitas antioksidan (IC 50 semakin kecil) yang ditunjukkan pada ekstrak etil asetat kulit batang $R$. apiculata, ekstrak metanol daun $R$. stylosa, ekstrak n-heksana kulit batang $R$. mucronata dan ekstrak etil asetat daun $R$. apiculata, kadar fenolat cenderung semakin tinggi. Hasil ini sesuai dengan aktivitas antioksidan ekstrak mangrove dari Sundarban (India) (Banerjee et al., 2008), mangrove $R$. stylosa dari Micronesia (Suhet al., 2014), dan ekstrak daun mangrove dari Setiu Wetland Malaysia (Malik et al., 2017).

Senyawa fenolat berfungsi sebagai pelindung tumbuhan dari kerusakan akibat cahaya yang berlebihan dengan carabertindak sebagai antioksidan, dan melindungi mangrove dari kerusakan akibat herbivori, patogen, dan radiasi sinar ultraviolet(photodamage)(Banerjee et al., 2008; Kenneth dan belema, 20117; Pawar dan dasgupta, 2018). Kemampuan ekstrak

Tabel 1. Hasil Ekstraksi Kulit batang dan daun Mangrove dari Teluk Awur Jepara

\begin{tabular}{|c|c|c|c|c|c|}
\hline No & & & Pelarut & $\begin{array}{c}\text { Berat } \\
\text { Ekstrak (g) }\end{array}$ & $\begin{array}{c}\text { Rendemen } \\
(\%)\end{array}$ \\
\hline \multirow{6}{*}{1} & \multirow{6}{*}{ R. mucronata } & \multirow{4}{*}{ Kulit batang } & Heksana & $0,15 \pm 0,06$ & 0,32 \\
\hline & & & Etil asetat & $0,75 \pm 0,10$ & 1,50 \\
\hline & & & Metanol & $12,69 \pm 1.45$ & 25,38 \\
\hline & & & Heksana & $0,64 \pm 0,09$ & 1,28 \\
\hline & & \multirow[t]{2}{*}{ Daun } & Etil asetat & $2,64 \pm 0,54$ & 5,28 \\
\hline & & & Metanol & $11,21 \pm 2,76$ & 22,42 \\
\hline \multirow{6}{*}{2} & \multirow{6}{*}{ R. apiculata } & \multirow{4}{*}{ Kulit batang } & Heksana & $0,15 \pm 0,07$ & 0,30 \\
\hline & & & Etil asetat & $0,35 \pm 0,11$ & 0,72 \\
\hline & & & Metanol & $11,34 \pm 1,89$ & 22,68 \\
\hline & & & Heksana & $1,15 \pm 0,44$ & 2,30 \\
\hline & & \multirow[t]{2}{*}{ Daun } & Etil asetat & $1,12 \pm 0,13$ & 2,25 \\
\hline & & & Metanol & $3,44 \pm 0,68$ & 6,88 \\
\hline \multirow{6}{*}{3} & \multirow{6}{*}{ R. stylosa } & \multirow{4}{*}{ Kulit batang } & Heksana & $0,16 \pm 0,08$ & 0,31 \\
\hline & & & Etil asetat & $0,16 \pm 0,05$ & 0,33 \\
\hline & & & Metanol & $9,67 \pm 1,23$ & 19,35 \\
\hline & & & Heksana & $0,72 \pm 0.17$ & 1,45 \\
\hline & & \multirow[t]{2}{*}{ Daun } & Etil asetat & $1,25 \pm 0.29$ & 2,50 \\
\hline & & & Metanol & $4,05 \pm 1,09$ & 8,11 \\
\hline
\end{tabular}




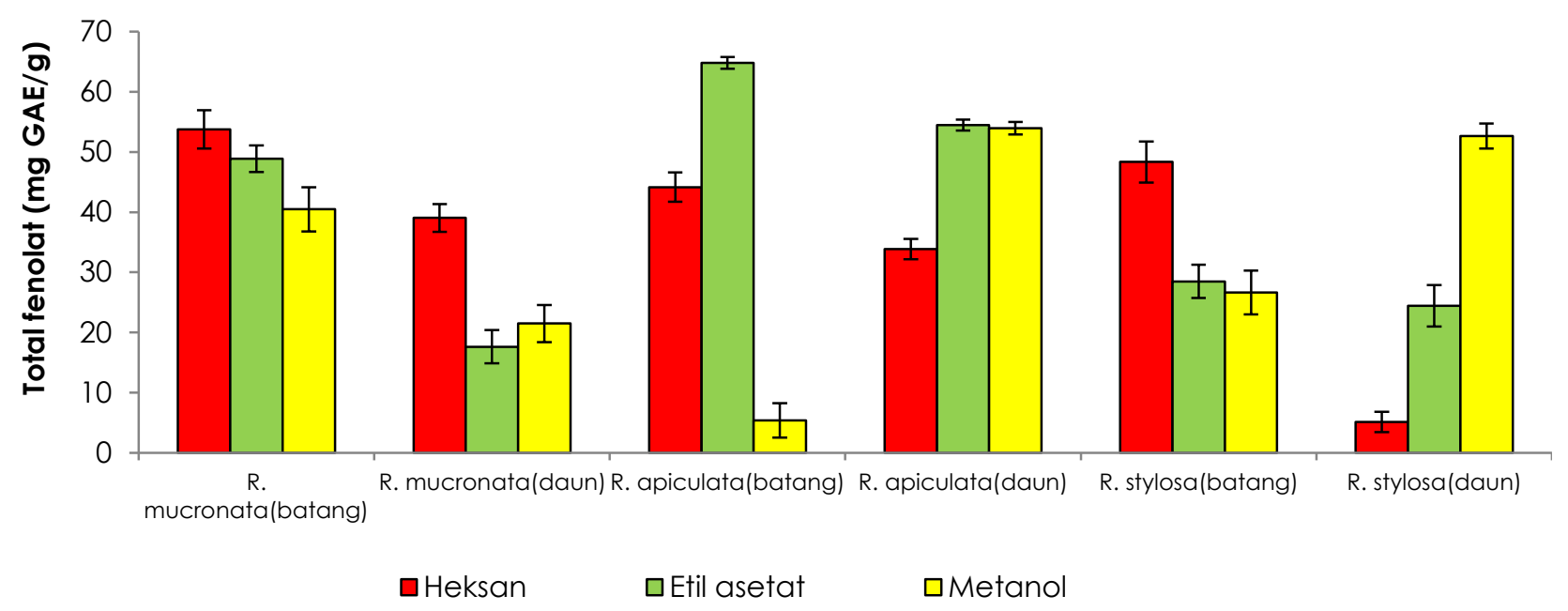

Gambar 1. Kandungan total fenolat ekstrak mangrove

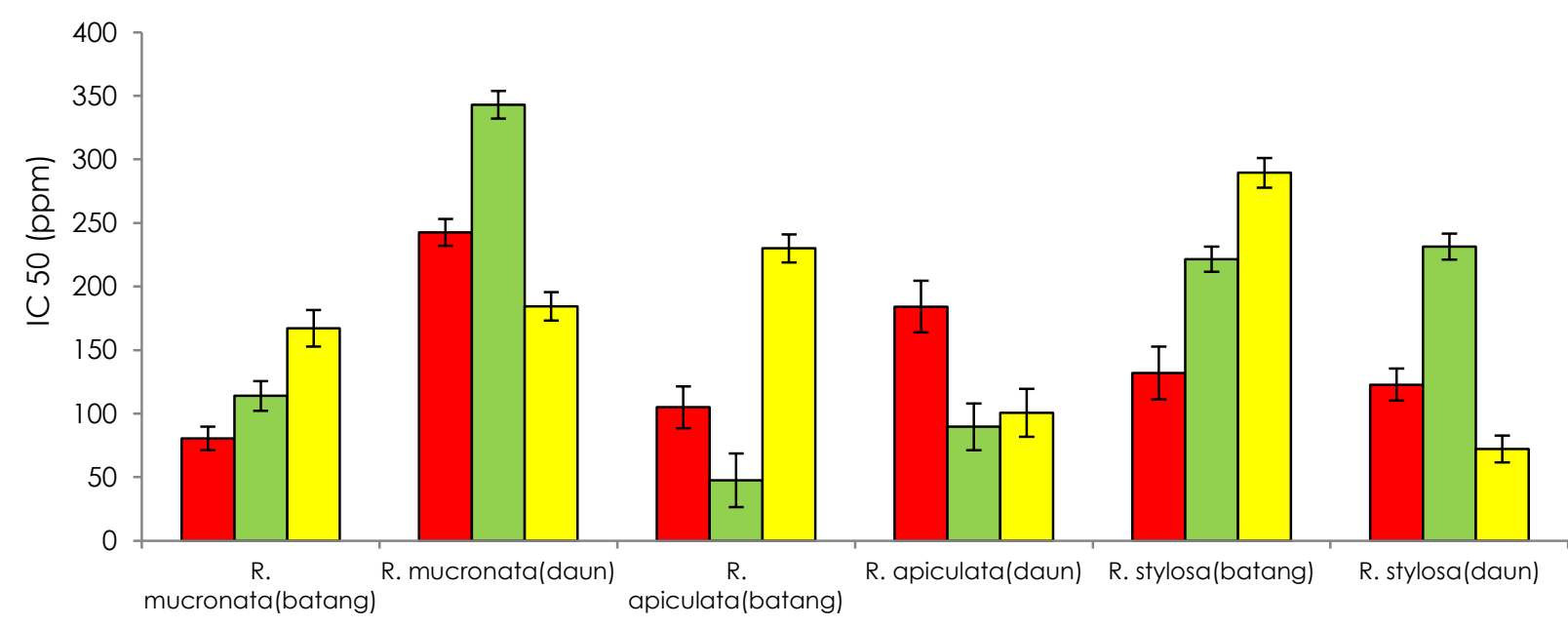

- Heksan aEtil asetat aMetanol

Gambar 2. IC $C_{50}$ Ekstrak mangrove

untuk meredam radikal DPPH terutama disebabkan sifat ekstrak yang mampu berperan sebagai agen pereduksi, karena potensial reduksi radikal fenolat lebih rendah daripada radikal alkil peroksil dan superoksida, sehingga fenolat dapat mereduksi / menonaktifkan dan meredam radikal bebas. Senyawa fenolat bereaksi lebih kuat dengan radikal peroksil daripada dengan DPPH (Fotiet al., 2008).Senyawa polifenol bersifat multifungsi karena dapat berperan sebagai agen pereduksi, pendonor hidrogen, dan peredam radikal oksigen, bahkan sebagai pengkelat logam pada beberapa kasus (Rice-Evans et al., 1996).

Senyawa fenolat bekerja sebagai antioksidan melalui pemutusan reaksi berantai (chain reaction) radikal dan mendonorkan atom hidrogen dari gugus $-\mathrm{OH}$ atau elektro sehingga dihasilkan radikal bebas yang lebih stabil (Nimse dan Pal, 2015) melalui dua mekanisme reaksi yaitu (1) Hydrogen Atom Transfer (HAT), kecepatan reaksinya dengan DPPH tergantung pada energy barrier pemindahan atom $\mathrm{H}$. Jika 
entalpi disosiasi ikatan antioksidan-H rendah, maka energi barrier juga rendah, yang berarti reaksi akan terjadi semakin cepat dan semakin mudah memberikan atom $\mathrm{H}$ kepada DPPH.Reaksi ini juga dipengaruhi oleh posisi atom $\mathrm{H}$ ortho dan gugus $\mathrm{NO}_{2}$ ortho pada kedua cincin fenil DPPH (Foti et al., 2008). Mekanisme (2) adalah Single Electron Transfer-Proton Transfer (SET-PT), yang berlangsung melalui 3 tahap reaksi yang melibatkan transfer elektron dari reduktor kepada DPPH diikuti dengan transfer proton kepada DPPH sehingga terbentuk DPPH-H non radikal (Foti et al., 2008; Hamlaoui et al., 2018), delokalisasi elektron dalam molekul DPPHdan intensitas warna unguberkurang (berubah menjadi kuning muda) (Molyneux, 2004).

Reaksi DPPH dengan senyawa fenolat berbanding lurus dengan jumlah hidrogen dari gugus hidroksil, struktur molekul dan posisi gugus hidroksil $(-\mathrm{OH})$ pada senyawa fenolat. Senyawa fenolat yang mempunyai gugus hidroksil pada posisi ortho dan para terhadap gugus-OR, biasanya memiliki aktivitas antioksidan yang kuat (Hamlaovi et al., 2018). Aktivitas peredaman radikal bebas DPPH oleh ekstrak mangroveRhizophora membuktikan bahwa mangrove memiliki kemampuan sebagai antioksidan serta menggambarkan keefektifan, kemampuan pencegahan dan mekanisme perbaikan dalam mengatasi kerusakan pada sistem biologis (Vimala et al., 2003).

\section{KESIMPULAN}

Hasil uji terhadap 18 ekstrak menunjukkan bahwa 1 ekstrak etil asetat kulit batang $R$. apiculata memiliki aktivitas antioksidan sangat kuat,3 ekstrak memiliki aktivitas antioksidan kuat yaitu ekstrak nheksana kulit batangR. mucronata, ekstrak etil asetat daun $R$. apiculata dan ekstrak metanol daun $R$. stylosa. Limaekstrak memilikiaktivitas sedang, 3 ekstrak memiliki aktivitas lemah, dan 6 ekstrak bersifat sangat lemah.

\section{DAFTAR PUSTAKA}

Abdurahman, N. H., Nitthiya, J. \& Omer, M. S. 2016. Composition and Biological
Activities as Mangrove Plants. Australian J. Basic App. Science. 10(4):1 14-139

Abidin, N.A.Z., Halim, N.H.A. \& Me. R. 2013. Basic Study of Chemical Constituents in R. Species. The Open Conference Proc. J. 4(Suppl-2, M7):27-28.

Banerjee, D.S. Chakrabarti, A., Hazra, K., Banerjee, S., Ray,J. \& Mukherjee,B. 2008. Antioxidant activity and total phenolics of some mangroves in Sundarbans African J. Biotechnol. 7(6):805-810,

Cruz S. M., Marroquín, N., Alvarez, L. E., Chang, D.E. \& Cáceres, A. 2015. Evaluation of Mangrove (Rhizophora mangle L.) products as coloring, antimicrobial and antioxidant agents. J. Phytocosmetics and Natural Ingredients, 2:1210-1215.

de-Faria, F.M., Almeida, A.C.A., Luiz-Ferreira, A., Takayama, C., Dunder, R.J., da Silva, M.A., Salvador, M.J., Abdelnur, P.V., Eberlin, M.N., Vilegas, W. \& Toma, W., 2012. Antioxidant Action of Mangrove Polyphenols against Gastric Damage Induced by Absolute Ethanol and Ischemia-Reperfusion in the Rat. The Sci. World J. 2012:9 pages

Foti, M.C., Daquino, C., Mackiel, D., DiLabio, G.A. \& Ingold, K.U. 2008. Reaction of Phenols with The 2,2-Diphenyl-1picrylhydrazyl Radical. Kinetics and DFT Calculation Apllied to Determine ArO-H Bond Dissosiation Enthalpies and Reaction Mechanism. J. Org. Chem. 73:9270-9282

Ghafar, M.F.A., Prasad, K.N., Weng \& Ismail,A.. 2010. Flavonoid, Hesperidine, Total Phenolic Contents and Antioxidant Activities from Citrus Species. African J. Biotechnol. 9(3):326-330

Hamlaovi, I., Bencheraiet, R., Bensegueni, R. \& Bencharif, M., 2018 Experimental and Theoritical Study on DPPH Radical Scavenging Mechanism of Some Calchone Quinoline Derivatives. J. Mol. Structure. 11 (56):385-389.

Jacoeb, A.M., Purwaningsih, S., \& Rinto. 2011. Anatomi, Komponen Bioaktif dan Aktivitas Antioksidan Daun Mangrove Api-api (Avicennia marina). J. Pengolahan Hasil Perikanan Indonesia. 14(2):143-152.

Kenneth, E.M. \& Belema, T. 2017. Comparative Evaluation of The Phenolic 
and Antioxidant propertise of Tke Leaves, Root, Stem Bark of Annona muricata. J. Pharmacog. Phytochem. 6(2):274-278.

Lü, J.M., Lin, P.H., Yao, Q. \& Chen, C. 2010. Chemical and Molecular Mechanisms of Antioxidants : Experimental Approaches and Model Systems. J. Cell. Mol. Med. 14(4):840-860

Malik, N.H., Zin, Z.M., Razak, S.B.A., Ibrahim, K. \& Zainol, M.K. 2017. Antioxidative Activities and Flavonoids Contens in Leaves of Selected Mangrove Species in Setiu Wetland Extracted Using Different Solvent. J. Sustain.Sci. Manag. 3:24-34

Maurya, S. \& Singh, D. 2010. Quantitative Analysis of Total Phenolic Content in Adhatoda Vasica Nees Extracts, Int. J. Pharm. Tech Res. 2(4):2403-2406

Mohsen, S.M. \& Ammar, A.S.M. 2009. Total Phenolic Contents and Antioxidant Activity of Corn tassel Extracts. J. Food Chem. 11 (2):595-598.

Molyneux, P. 2004. The Use of Stable Free Radical Diphenylpicrylhydrazyl (DPPH) for Estimating Antioxidant Activity. Songklanakarin. J. Sci. Technol. 26(2):211219.

Mouafi, F.E., Abdel-Aziz, S.M. Bashir, A.A. \& Fyiad, A.A. 2014. Phytochemical Analysis and Antimicrobial Activity of mangrove Leaves (Avicenna marina and Rhizophora stylosa) Against Some Pathogens. World App. Sci. J. 29(4):547554

Nimse, S.B. \& Pal, D. 2015. Free Radicals, Natural Antioxidants, and Their Reaction Mechanisms. The Royal Soc. Chem. 5:27986-28006

Patra, J.K., Dhal, N.K. \& Thatoi, H.N. 2011. In vitro bioactivity and phytochemical screening of Suaeda maritima (Dumort): A mangrove associate from Bhitarkanika, India. Asian Pacific J. Trop. Med. 4(9):727734

Paputungan, Z., Wonggo, D. \& Kaseger, B. E. 2017. Uji Fitokimia dan Aktivitas Antioksidan Buah Mangrove Sonneratia alba Di Desa Nunukan Kecamatan Pinolosian Kabupaten Bolaang Mangondow Selatan. J. Media Teknol. Hasil Perikanan.5(3):190-196
Pawar, S.S. \& Dasgupta, D. 2018. Quantification of Phenolic Content from Stem-Bark and Root of Hugonia mystax Linn. using RP-HPLC. J. King Saud University Sci. 30:293-300

Purwaningsih, S., Salamah, E., Sukarno, A.Y.P. \& Deskawati, E., Aktivitas Antioksidan Dari Buah Mangrove (Rhizophora mucronata Lamk) Pada Suhu Yang Berbeda. J. Hasil Pengolahan Perikanan Indonesia. 16(23):199-206

Rahim, A.A., Rocca, E., Steinmetz, J., Kassim, M.J., Ibrahim, M.S. \& Osman, H. 2008. Antioxidant activity of mangrove Rhizophoraapiculata bark extracts. Food Chem. 107:200-207.

Rice-Evans, C., Miller, N.J. \& Paganga, G. 1996. Structure Antioxidant Activity Relationships of Flavonoids and Phenolic Acids. Free Radical Biol. Med. 20(7):933956

Roby, M.H.H., Sarhan, M.A., Selim, K.A.H. \& Khalel, K.I., 2013. Evaluation of antioxidant activity, total phenols and phenolic compounds in thyme (Thymus vulgaris L.), sage (Salvia officinalis L.), and marjoram (Origanum majorana L.) extracts. Industrial Crops and Products, 43:827-831.

Saha, M.R., Hasan, S.M.R., Akter, R., Hossain, M.M., Alam, M.S., Alam, M.A. \& Mazumder, M.E.H., 2008. In vitro free radical scavenging activity of methanol extract of the leaves of Mimusops elengi linn. Bangladesh J. Veteriner Med. 6(2):197-200

Suh, S.S., Hwang, J.M., Park, H.S. \& Lee, T.K. 2014. Phenol content, antioxidant and tyrosinase inhibitory activity of mangrove plants in Micronesia. Asian Pacific J. Trop. Med. 7(7):531-535

Vimala, S., Adenan, M.I., Ahmad, A.R. \& Shahdan, R. 2003. Nature's Choice to Wellness Antioxidant Vegetables/Ulam. Forest Research Institute Malaysia, Kuala Lumpur, 31-33.

Waddington, R.J., Moseley, R. \& Embery, G. 2008. Periodontal Disease Mechanisms: Reactive Oxygen Species: A Potential Role in The Pathogenesis of Periodontal Diseases. Oral Diseases, 6(3):138-151. 
Yogananth, N., Anuradha, V., Ali, M.Y.S., Muthezhilan, R., Chanthuru, A. \& Prabu, M.M., 2015. Chemical properties of essential oil from Rhizophora mucronata mangrove leaf against malarial mosquito Anopheles stephensi and filarial mosquito Culex quinquefasciatus. Asian Pacific J. Trop. Disease, 5:S67-S72. 